\title{
Toys, 'tis and Theme
}

In this issue, we are reminded that the changing status of English in the world depends on its changing relationship to other languages - both large and small. Is English really a killer language? In a passionate contribution from Cameroon, Globalising a local language and localising a global language: the case of Kamtok and English in Cameroon Aloysius Ngefac seems to regard it so. Or rather, he argues in a more nuanced way, that too much attention has been spent implementing international English in Cameroon to the detriment of widening the appreciation of a local language, Kamtok - sometimes also called Cameroon Pidgin English. This contest between varieties of English is now as much a part of the story of global English as the contest between English and regional languages, or between English and other former colonial languages.

ET regularly provides a forum for contributors to report on the use of English in advertising, shop signs and global brands. In this issue, Carmen Luján-García explores a related, but perhaps even more sensitive kind of text: leaflets produced to promote toys to children in Spain. It used to be that most of the world's children were first introduced to English at secondary school, but now most first encounter English out of school at an early age. In many Asian countries, it is the amah, ayah or maid who now first brings English into middle-class families. But everywhere, it seems, young children are learning to associate English with play as well as with homework.

In this issue of ET, several contributors thump their tubs. Kamtok Amorey Gethin argues that linguists just can't get the analysis of some and any right. Wayne Rimmer, meanwhile, shows us that learners of English are not just consumers of the linguistic norms made by native-speakers but innovate themselves - perhaps creating a new source of linguistic change. And Meredith Stephens takes issue with an article from ET 101 by Jeffrey Gil. Gil argued that Australians were relying too much on Asians being able to speak English, and they needed to improve their own foreign language skills. The situation in Japan, Meredith Stephens tells us, has moved on: there is a greater expectation that business will be undertaken in English, but there is also an increase in the number of Australians able to speak Japanese. Bilingualism, it seems, is increasingly expected on the part of both Australians and Japanese. The ET editors are grateful to Meredith for responding on this matter, and we would like to encourage other readers to contact us with feedback, whether with a view to publication or not.

Dennis Gailor takes a historical view, of the development of contractions such as don't and it's in Early Modern English. And we have a couple of articles which worry about metalinguistic aspects of English as a global language. Alan Runcieman wonders why the word 'English' seems to be positioned first (the theme) in most phrases relating to English as a world language. Matthew Watterson, meanwhile, reviews the range of phrases now used to describe 'English as a global language'.

That leaves us with one last article: a contribution by Jeffrey Gil on the debate now raging in some quarters as to whether the Chinese language is growing so fast that it will eventually replace English as the world's lingua franca. This is a useful contribution to a topic which we will surely return to.

This issue of ET is the first using a streamlined typesetting process, introduced by Cambridge University Press. Do you like the new look of the English Today? Do let us know. The Editors

The editorial policy of English Today is to provide a focus or forum for all sorts of news and opinion from around the world. The points of view of individual writers are as a consequence their own, and do not reflect the opinion of the editorial board. In addition, wherever feasible, ET generally leaves unchanged the orthography (normally British or American) and the usage of individual contributors, although the editorial style of the journal itself is that of Cambridge University Press. 